\title{
КІЛЬКІСНІ ХАРАКТЕРИСТИКИ КОМПЛЕМЕНТАРНОСТІ ЄДИНО ІНФОРМАЦІЙНО СИСТЕМИ ОХОРОНИ ЗДОРОВ'Я ТА ІНФОРМАЦІЙНО СИСТЕМИ УПРАВЛІННЯ ОБІГОМ ЛІКАРСЬКИХ ЗАСОБІВ
}

\author{
Л. Ю. Бабінцева
}

Національна медична академія післядипломної освіти імені П. Л. Шупика

\begin{abstract}
Створення та впровадження інформаційно системи управління обігом лікарських засобів (лікарським забезпеченням) $є$ одним із найважливіших елементів державного регулювання фармацевтичного сектора охорони здоров'я. Вперше обґрунтовано функціонування в єдиному медичному інформаційному просторі двох інформаційних систем - єдино системи охорони здоров'я та єдино інформаційно системи управління обігом лікарських засобів. Доведено необхідність такого функціонування за принципом комплементарності, для чого запропоновано узагальнюючі та технологічні коефіцієнти.
\end{abstract}

Ключові слова: єдиний інформаційний простір, єдина інформаційна система охорони здоров'я, єдина фармацевтична інформаційна система, комплементарність інформаційних систем, конгруентність інформаційно системи.

\section{КОЛИЧЕСТВЕННЫЕ ХАРАКТЕРИСТИКИ КОМПЛЕМЕНТАРНОСТИ ЕДИНОЙ ИНФОРМАЦИОННОЙ СИСТЕМЫ ЗДРАВООХРАНЕНИЯ И ИНФОРМАЦИОННОЙ СИСТЕМЫ УПРАВЛЕНИЯ ОБОРОТОМ ЛЕКАРСТВЕННЫХ СРЕДСТВ}

Л. Ю. Бабинцева

Национальная медицинская академия последипломного образования имени П. Л. Шупика

Создание и внедрение информационной системы управления оборотом лекарственных средств (лекарственным обеспечением) является одним из важнейших элементов государственного регулирования фармацевтического сектора здравоохранения. Впервые обосновано функционирование в едином медицинском информационном пространстве двух информационных систем - единой системы здравоохранения и единой информационной системы управления оборотом лекарственных средств. Доказана необходимость такого функционирования по принципу комплементарности, для чего предложены обобщающие и технологические коэффициенты.

Ключевые слова: единое информационное пространство, единая информационная система здравоохранения, единая фармацевтическая информационная система, комплементарность информационных систем, конгруэнтность информационной системы.

\section{QUANTITATIVE CHARACTERISTICS OF COMPLEMENTARY INTEGRATED HEALTH CARE SYSTEM AND INTEGRATED MEDICATION MANAGEMENT INFORMATION SYSTEM}

L. Yu. Babintseva

National Medical Academy of Postgraduate Education by P. L. Shupyk

Creation and implementation of management information system trafficking of drugs (drug coverage) is one of the most important elements of state regulation of the pharmaceutical sector health. For the first time creation of two information systems: integrated medication management information system and integrated health care system in an integrated medical information area, operating based on the principle of complementarity was justified. Global and technological coefficients of these systems' functioning were introduced.

Key words: integrated information space, integrated information health care system, integrated pharmaceutical information system, complementarity of information systems, congruence of information system.

(с) Л. Ю. Бабінцева 
Вступ. У концепції розвитку фармацевтичного сектору галузі охорони здоров'я України наголошується, що головну роль у обігу лікарських засобів (ЛЗ) відіграє пацієнт, тобто розвиток фармацевтичного сектору є невід'ємною частиною охорони здоров'я та передбачає реформування всіх ланок обігу лікарських засобів: від розробки, випробування до застосування.

Для формалізації багатоаспектних даних про ЛЗ використовуються різноманітні підходи, системи класифікації і кодування інформації. Сьогодні бази даних (БД) про ЛЗ розрізнені, часто несумісні або дублюють один одного та мають короткий життєвий цикл при значних матеріальних витратах. Розробка існуючих до тепер подібних баз даних проводиться без відповідної координації і на різних методологічних принципах.

Вкрай важливими функціями можуть стати також облік інформації про побічну дію лікарських засобів; моніторинг цін на лікарські засоби і вироби медичного призначення та моніторинг їх імпорту/експорту.

Деякі з перелічених функцій можливі як у єдиній інформаційній системі охорони здоров'я (ЄICO3), наприклад, моніторинг цін на ЛЗ, так і в запропонованій нами інформаційній системі управління обігом лікарських засобів (ІСУОЛЗ). Проте вкрай важливими $є$ джерела інформації. Якщо інформаційний ресурс для ЄICO3 формується зі звітів закладів охорони здоров'я (3О3) на основі закупівельних цін, то для ICУОЛЗ - основою є середні ціни на ринку.

Наявність двох джерел інформації, власне кажучи, i $€$ основою державного контролю функціонування ринкових структур.

Нагляд за фармацевтичною діяльністю та контролем над безпекою, ефективністю й якістю лікарських засобів $є$ основою для об’ єктивного аналізу ситуації у сфері обігу Л3, що складається в регіонах, iі професійного оцінювання та прийняття рішень.

Раніше нами сформульовано такі основні показники концепції управління обігом лікарських засобів [1]:

- виключення дублювання введення інформації та підвищення іiі достовірності за рахунок ототожнення раніше введеної інформації;

- можливість обміну повідомленнями між територіально розподіленими структурами;

- підвищення ефективності державного регулювання сфери обігу Л3;

- забезпечення автоматизованого інформаційного обміну між територіальними органами МОЗ України;
- організація взаємодії з інформаційними системами інших міністерств і відомств у рамках створення електронного уряду.

Мета роботи: обгрунтування принципів функціонування в єдиному медичному інформаційному просторі двох інформаційних систем (IC) - єдиної системи охорони здоров'я та єдиної інформаційної системи управління обігом лікарсыких засобів, що мають працювати за принципом комплементарності.

Результати та ïx обговорення. Впровадження ICУОЛЗ забезпечить ефективний моніторинг та оперативне прийняття управлінських рішень на основі аналізу накопиченої інформації, дозволить повною мірою здійснювати контрольно-наглядові функції за фармакологічною діяльністю 303.

Для медичних організацій, що здійснюють фармацевтичну діяльність, система дозволяє налагодити ефективний облік діяльності організації, надає можливість своєчасного отримання та використання інформації про передові досягнення в області фармації. Для населення єдиний інформаційний банк даних ІСУОЛЗ дозволяє надавати кількісну й якісну інформацію про лікарські засоби.

На основі ІСУОЛЗ можливе також вирішення таких завдань:

1) забезпечення постійного та зручного доступу до розподілених інформаційних ресурсів системи для оперативного прийняття рішень;

2) реєстрація, облік та оперативне оновлення інформації за всіма структурними блоками;

3) забезпечення оперативності отримання необхідної інформації з будь-якого відомчого рівня (державного, обласного, територіального) у вигляді звітів, довідок тощо для прийняття рішення з різних питань;

4) забезпечення доступу широкого кола користувачів до певної інформації.

Існуючі програмні засоби у сфері обігу лікарських засобів не орієнтовані на введення та зберігання первинної інформації на рівні району/міста. Збір зведеної інформації проводиться на обласному та республіканському рівнях. При цьому не автоматизовано процес відправки звітної інформації на вищі рівні. Дані, що передаються, та нормативно-довідкова інформація не синхронізовані. Не передбачено одночасне оновлення використовуваних програмних засобів.

Значний обсяг даних, накопичений у результаті експлуатації комп'ютерних програмних продуктів у сфері обігу лікарських засобів, не може бути використаний повною мірою всіма учасниками інформаційного обміну. Лікарні, медичні організації, аптечні установи, що є безпосередніми користувачами аналі- 
тико-статистичних даних, не можуть отримати необхідну за регламентом інформацію в режимі онлайн.

Накопичений за останні роки досвід показав, що неможлива взаємодія різних систем за відсутності єдиного стандарту повідомлень, що об'єднує різні системи в єдину розподілену мережу даних. А для забезпечення безперебійної роботи розподілених об' єктів потрібен постійний стійкий зв' язок між ними, що підтримує технологія серверів повідомлень.

Функціонування підсистеми ІСУОЛЗ у рамках ЄICO3 має надавати додаткову важливу інформацію для державного та регіонального управління. Нами запропоновано три нових кластери інформації.

Перший: використання ліків у різних регіонах при наявності Л3 у сховищах. Забезпечує надання управлінської інформації про місцеву логістику. Другий: порівняння ефективності використання ЛЗ (наприклад, генериків і оригінальних Л3). Третій кластер: планування закупівель і наявність ліків. Отримання зазначеної інформації, на наш погляд, може мати вирішальне значення для управління системою охорони здоров'я, зокрема для розвитку профілактичної медицини.

Проте, не менш важливим є отримання кількісних характеристик сумісного функціонування двох інформаційних систем, оскільки їхньою головною метою $\epsilon$ забезпечення здоров'я населення.

Нами розроблено кількісні характеристики їх взаємодії, а саме: дві групи коефіцієнтів - узагальнюючі та технологічні.

До узагальнюючих віднесли такі коефіцієнти:

1) коефіцієнт комплементарності $\left(K_{c}\right)$, що представляє відношення запитів на цільову інформацію з іншої системи до загальної кількості запитів:

$$
K_{c}=\frac{\eta_{p}}{\eta_{V}},
$$

де $\eta_{p}$ - кількість цільових запитів, $\eta_{V}$ - загальна кількість запитів;

2) коефіцієнт симетричності звернень між системами $\left(K_{s}\right)$, що представляє відношення сумарних звернень від однієї системи до другої:

$$
K_{s}=\frac{\theta_{l \rightarrow z}}{\theta_{z \rightarrow l}},
$$

де $\theta_{l}$ - звернення від ІСУОЛЗ до СІСО3, $\theta_{z}-$ навпаки.

До основних технологічних:

1) коефіцієнт рівномірності звернень від регіонів $\left(A_{p}\right)$, що дорівнює відношенню середньоквадратичного відхилення звернень до загальної кількості звернень:

$$
A_{r}=\frac{\sigma_{r}}{\eta_{V}},
$$

де $\sigma_{r}$ - середньоквадратичне відхилення звернень від регіонів, $\eta_{V}$ - загальна кількість запитів;

2) коефіцієнт часової асиметрії $\left(A_{t}\right)$, що дорівнює відношенню середньоквадратичного відхилення звернень до загальної кількості звернень:

$$
A_{t}=\frac{\sigma_{t}}{\eta_{V}}
$$

де $\sigma_{t}-$ середньоквадратичне відхилення звернень у часі, $\eta_{V}$ - загальна кількість запитів.

До інших технологічних коефіцієнтів віднесли: коефіціснт кластерного інформаційного «навантаження) на групи критеріїв, що містяться в системах; коефіцієнт точкового інформаційного «навантаження») на окремі критерії, що містяться в системах; коефіцієнт адекватного наповнення інформацією, що забезпечує зіставлення своєчасності внесення аналогічних показників до обох систем тощо.

Взаємодія двох IC, гармонізація та комплементарність їх роботи може бути забезпечена різними шляхами. Забезпечення якісного надання медичної допомоги можливе лише при гарантуванні сумісності та взаємодії ІСУОЛЗ із ЄICO3 та іншими суміжними системами. Останнє можливо лише за рахунок дотримання єдиних організаційних, методологічних i програмно-технічних принципів, насамперед, шляхом уніфікації значень показників, шо включаються у відомості про об' єкти обліку, на основі застосування єдиних стандартів, класифікаторів і довідників, а також застосування для інформаційної взаємодії з суміжними IC єдиних протоколів телекомунікаційних мереж, форм документів і форматів даних, що передаються на електронних носіях.

Проведені пілотні дослідження показали, що практичне застосування запропонованих коефіцієнтів виявилося важким.

Насамперед дивним виявилося те, що більшість інформаційних систем не веде статистику запитів лікарів до них. Зрозуміло, очевидними є запити лікарів щодо довідкової інформації про пільговиків, їхнього ставлення до затверджених у країні реєстрів осіб, які страждають рідкісними (орфаними) захворюваннями, нормативних документів про формування запитів на лікарські препарати тощо.

Настільки ж явними $€$ запити щодо нормативно-методичної допомоги (наприклад, ознайомлення з наказами Міністерства охорони здоров'я про організацію роботи 3 первинною обліковою медичною документацією тощо), статистики захворюваності в регіоні. 
Сдиними значущими (за частотою) запитами стали: аналітичні огляди 3 питань застосування стандартів, термінів, понять, що використовуються в світовій охороні здоров'я, матеріали 3 доказової медицини (зокрема систематичних оглядів із певного захворювання).

Висновки. Фармацевтичний сектор характеризується своєю значною мультидисциплінарністю. В прикладному аспекті інформація, яку отримує користувач, повинна мати суттєву комплементарність. Якщо користувач - фахівець медичного напряму, дані

\section{Література}

1. Бабінцева Л. Ю. Засади створення державної системи інформаційного моніторингу фармацевтичного ринку / Л. Ю. Бабінщева // Медична інформатика та інженерія. 2012. -№ 1. -C. 33-36.

2. Мінщер О. П. Засади створення єдиної державної системи інформаційного забезпечення закладів охорони здоро- мають конкретно стосуватися впливу ЛЗ на організм людини та надавати йому всю необхідну інформацію для прийняття рішень щодо діагностики стану людини та вибору відповідної корекції.

Впровадження ICУОЛЗ $є$ одним із важливих елементів державного регулювання фармацевтичного сектора охорони здоров'я. Задля кількісних характеристик сумісного функціонування двох інформаційних систем запропоновано узагальнюючі та технологічні коефіцієнти.

в'я/ О. П. Мінцер, Л. Ю. Бабінцева, М. В. Банчук // Медична інформатика та інженерія. -2011. - № 3. - С. 5-12.

3. Баб̈інцева Л. Ю. Концепція інформатизації ринку лігарських засобів та фармацевтичних послуг / Л. Ю. Бабінцева // Медична інформатика та інженерія. - 2010. - № 2. C. $44-48$. 